\title{
PERCEPTIONS OF INDUSTRY 4.0 IN ViSEGRAD FiRMS
}

\author{
Marta Götz ${ }^{1}$, Magdolna Sass ${ }^{2}$, Andrea Éltető ${ }^{3}$
}

\begin{abstract}
The definition and understanding of the Industry 4.0 concept vary widely in the literature and among practitioners. The objective of our research was to analyse the perceptions of Industry 4.0 in the Visegrad companies and the explanations for the differences thereof; and second, to compare perceptions of Industry 4.0 between Visegrad firms and experts. Our article relies on a combined methodology: analysis of literature and of information gained from questionnaire-based semi-structured interviews, conducted with randomly selected company representatives, academic and industry experts, and representatives of government agencies. Our results show that most Visegrad firms identify Industry 4.0 only with a limited set of selected new technologies, while experts usually have a more complex understanding of it, identifying it with a new business model. It would be important to have a clearly defined concept in order to elaborate related nationwide strategies and related economic and other policy tools.
\end{abstract}

\section{Keywords}

Industry 4.0, Visegrad Countries, Technology

\section{Introduction}

The Visegrad countries are not among the leaders in Europe or the world economy in terms of innovation or the various areas of new technologies (UNIDO, 2020; PIE Report, 2019; Rostkowski, 2019; Fifeková et al., 2018; Szalavetz, 2016 or see Cséfalvay, 2019 for sectoral differences). However, many companies operating in these four countries are aware of the opportunities offered by Industry 4.0 and its importance.

In this paper, we present the results of a research project, which addressed the impact of Industry 4.0 on several areas of the Visegrad economies. One part of our research was devoted to the analysis of the perception and understanding of Industry 4.0 by Visegrad firms, as already at the start of the project we found significant differences in this area.

\footnotetext{
${ }^{1}$ Vistula University, Stokłosy 3/107 b, 02-787 Warszawa, Poland. E-mail: m.gotz@ vistula.edu.pl.

${ }^{2}$ Centre for Economic and Regional Studies, Institute of World Economics, 1097 Budapest, Tóth Kálmán u 4, Hungary. E-mail: sass.magdolna@krtk.mta.hu.

${ }^{3}$ Centre for Economic and Regional Studies, Institute of World Economics,1097 Budapest, Tóth Kálmán u 4, Hungary. E-mail: elteto.andrea@krtk.mta.hu.
} 
Perception is a complex, cognitive process widely discussed in psychology (Angell, 1906, Lewis, 2001) and it is easier in the case of an object, but the notion of Industry 4.0 is abstract. We define perception as in the Oxford Language vocabulary "the way in which something is regarded, understood, or interpreted". ${ }^{4}$ Despite of the growing popularity of industry 4.0, as noted in Ciffolilli and Muscio (2018), there is no official single definition of Industry 4.0 activities and technologies in the literature; and the perimeter of this concept remain non-consensual. There are scholars who use advanced bibliometric methods and through the frequency of occurrence of specific words, attempt to define Industry 4.0 in the context of specific technologies such as 3D printing or big data or autonomous robotics (Corradini, Santini and Vecciolini, 2021, Obermayer et al., 2021). The gap between rising popularity contrasted with conceptual ambiguity was the starting point for our analysis. Conceptual perimeters of Industry 4.0 are still inconclusive. Thus, we try to fill two gaps: tracing differences or similarities in the perception of Industry 4.0 in the Visegrad countries' companies; and comparing perceptions of Industry 4.0 between Visegrad firms and experts.

Our article relies on a combined methodology: on the analysis of the literature and the analysis of information gained from questionnaire-based semi-structured interviews, conducted with company representatives, academic and industry experts and representatives of government agencies. Our results reinforce the conceptual ambiguity described above. We find that Visegrad companies consider Industry 4.0 more as a set of technologies, but perception can differ according to foreign or domestic ownership and sector of activity. On the other hand, Visegrad experts usually have a more complex understanding of it, identifying it with a new business model. We underline, that this conceptual problem results in problems for the elaboration of national strategies and related policy tools.

The paper is organised as follows. First, we present a review of the literature concerning the perception of Industry 4.0, including the results of a few empirical studies. Second, we present our methodology. Third, the results of the interviews by country are presented, and then a discussion of the results follows. The last section concludes.

\section{The Importance and Perception of Industry 4.0}

Industry 4.0 has become an important and widely used concept in the economic and business literature recently. There is a wide discussion in the literature, on the opportunities and changes Industry 4.0 may bring to catching-up economies and individual firms. There is an agreement about the uncertainties surrounding the various impacts of Industry 4.0, e.g. whether it induces technology unemployment and downgrading because of reshoring or upgrading (Petropoulos, 2017; Segal, 2018; Szalavetz and Somosi, 2019). However, the micro and macro-level impacts of these technologies may without doubt be substantial. Industry 4.0-related new technologies may radically reshape product market competition (Aghion et al. 2017), may change jobs and the labour market (Acemoglu and Restrepo, 2020) as well as introduce fundamental changes in the governance of the firms (Yermack, 2017).

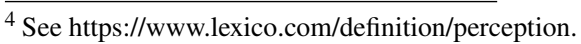


In the literature, we can find various definitions and explanation of Industry 4.0. However, the rising popularity of Industry 4.0 goes together with conceptual ambiguity as there is no clear and commonly accepted definition of the term. Industry 4.0 can be perceived as a set of multiple new technologies, which (can be or) are applied in production processes and the organisation and control of value chains ${ }^{5}$. Indeed, the original definition of Klaus Schwab (2016) identifies Industry 4.0 with a set of different technologies. These new technologies are supposed to alter manufacturing radically and to blur the boundaries between physical and digital production. They enable more flexible work organisation, may change substantially supply chain systems and decision-making processes. The three main advantages associated with Industry 4.0 are vertical integration, horizontal integration and end-to-end engineering (Kagermann et al., 2013). Thus, these new technologies create vast opportunities for the firms in terms of improving their efficiency, competitiveness and profitability as well as their ability to adapt flexibly to unique circumstances (Bauer et al., 2015). These technologies hence make companies interested in such solutions and firms are even forced by competition to apply them (Asadollahi-Yazdi et al., 2020). Such technologies are among others robotics, Artificial Intelligence, 3D printing, additive manufacturing, big data analytics, digitalisation, automation, etc., which allow firms to improve the efficiency of various production processes radically.

Besides the changes based on the application of these technologies, which fit into the existing strategies of the firms, Industry 4.0 related technologies also allow firms to change their strategies completely and elaborate entirely new and more successful strategies through embracing the opportunities brought over by these new technologies (Kagermann et al., 2013). In our understanding, while the first approach, i.e. inserting these new technologies into existing processes and strategies of firms, may result in more efficient, productive and profitable company processes, the second approach, i.e. applying completely new strategies, based on the opportunities provided by Industry 4.0, is the one, which may reap the full benefits of these various new technologies. Thus, in our opinion, not only the actual physical products and production are affected by Industry 4.0 but also the nature of the business itself, its organisation and its strategy - and this poses a real challenge for firms (see, e.g. Dremel et al., 2017). According to Bharadwaj and Venkrataman (2013), actually, there is a need for the fusion of IT and business strategies, which would lead to a digital business strategy, which can be deemed as essential for firms' competitiveness in the Industry 4.0 era. Buckley and Strange (2015) argue that multinational companies' strategies are changing as new technologies enabled the value chains to be more disaggregated and located in numerous locations. According to Mudambi et al. (2018), digital multinationals are expanding rapidly, outgrowing other multinationals and disrupting internationalisation models and patterns.

In practice, based on a thorough review of the literature, Oztemel and Gursev (2020) point to the fact that while academic research concentrates on understanding and defining the concept "Industry 4.0", companies usually focus on the change of the production process,

\footnotetext{
${ }^{5}$ For a list of various definitions see https://www.i-scoop.eu/industry-4-0/, Tay et al. (2018) or Oztemel and Gursev (2020).
} 
products and customers. Thus, companies often neglect the understanding of the features and content of Industry 4.0 and what it offers them in terms of changes in business strategy. Furthermore, according to the results of empirical studies, firms perceive Industry 4.0 and the related new technologies differently. In the case of Mexican automobile distribution companies, Hernández et al. (2019) identified three distinct groups in terms of their perception Industry 4.0, which differ from each other in the evaluation of the use of Industry 4.0 related technologies in the areas of the process, product, persons, technology, business and social responsibility. Based on semi-structured company interviews, Horváth and Szabó (2019) showed differences in perceptions between "Industry 4.0 suppliers", who first of all emphasised the technology side and "Industry 4.0 users", who highlighted the management aspects of Industry 4.0. They also found that the interviewees perceived digitalisation as the most crucial issue, and in their understanding, Industry 4.0 was a subcategory to that. Furthermore, Horváth and Szabó (2019) emphasised differences between multinational companies and small and medium-sized enterprises in Hungary in terms of driving forces and barriers related to Industry 4.0. Additionally, Veugelers et al. (2019) confirmed the trend towards a digital divide between European companies, indicating the different perception and application of new digital technologies. As a consequence, the gap widens between "digital" and "non-digital" firms in terms of their innovativeness, job creation ability and profitability. Oztemel and Gursev (2020) showed that in the US, companies identified Industry 4.0 with one related technology: industrial internet or the internet of things, which is indicated by the fact that in March 2014 the leading US multinationals founded the Industrial Internet Consortium (IIC), the aim of which is to bring together "operational systems" and information technology and help this process by identifying, assembling, testing and promoting best practices ${ }^{6}$. Other government initiatives from the United Kingdom, Taiwan, Japan, South Korea, China and Turkey illustrate well the different perceptions and emphasis of governments and/or firms in connection with Industry 4.0 (Oztemel and Gursev, 2020). Furthermore, there is high uncertainty and lack of knowledge about the real impact and contribution of the Industry 4.0 related technologies in emerging economies in general (Dalenogare et al., 2018).

Based on the above review of the literature, which indicates a relative lack of analysis about the Visegrad countries and very diverse results, we would like to address first, the question how Industry 4.0 is perceived in the Visegrad countries and what explains differences in perceptions; and second, we compare perceptions of Industry 4.0 of firms on one hand and experts on the other hand.

$\overline{{ }^{6} \text { See https://www.iiconsortium.org/about-us.htm. }}$. 


\section{Research Question and Methodology}

In this article we try to evaluate whether Visegrad firms perceive Industry 4.0 merely as a set of new technologies, which can be operated and integrated into their existing systems and strategies or rather as a development, which offers them a new way of looking at their business and thus as one, which enables them to change and renew their strategies fundamentally. Furthermore, we wanted to know if the perception of companies differs significantly from that of the experts.

In our research, we relied on a mixed method. First, we based our study on a critical literature review. It helped us to design a questionnaire with open questions for our interviews. In the field study, we applied questionnaire-based semi-structured in-depth interviews. The sample surveyed in all countries intends to ensure a diversity of views and opinions, so in addition to large multinational companies and small businesses (SMEs), there were representatives of governmental agencies, think-tanks, scholars from universities included. The interviews were taken in the period between December 2019 and August 2020 and lasted between 30 and 60 minutes. They were conducted live, by phone or on the internet (skype). We used the same questionnaire in all four countries. To assure confidentiality, all respondents remain anonymous.

The number of interviews varied from country to country. The largest number of interviews were conducted in Poland and Hungary. In Hungary, we interviewed four representatives of Hungarian subsidiaries of foreign multinational companies (F); four representatives of Hungarian-owned firms (H); three academic experts on Industry 4.0 (working in academic institutions or universities) (U), and two industry experts (I). In Poland, seven experts (E), five scholars (A) and four company representatives (B) were interviewed, including two foreign-owned and two domestically owned firms. We evaluated our samples as having a right combination of theoretical and practical experts in the area and practitioners having the first-hand experience with Industry 4.0. We focus in this article on Poland and Hungary where we have the highest number of interviews, but we added the results of the Czech and Slovak surveys too. In Czechia, six interviews were conducted, including three interviews with company representatives; two experts from the government and one from an international organisation. In Slovakia, similarly, six interviews were taken, including similarly three interviews with the representatives of foreign-owned and domestic firms and three interviews with experts (from a ministry, from an association of producers and from a university). Though our sample is limited in terms of numbers, the high level of similarity of answers received from companies on one hand and from the experts on the other hand induces us to think that our results can be generalised for the Visegrad countries. The data and information collected during the interviews were analysed according to the ways recommended by the literature. As suggested by Miles and Huberman (1994) analysing collected data should be done in three steps starting with data reduction, followed by data display, to final conclusion-drawing and verification. First analysis began already with the transcribing the interviews. Thanks to data display, obtained information and insight were compressed to extract the appropriate conclusions and then to give the findings proper structure (Osarenkhoe, Fjellström, Abraha and Awuah, 2020). 


\section{Differences in Perceptions of Industry 4.0 Related Technologies in the Visegrad Countries}

Our surveys proved similarities in the analysed Visegrad countries in terms of the perception of Industry 4.0 at the company level. Our additional interviews gave insights into the various explanations concerning these differences. Information from expert interviews underlined the differences between firms' and experts' perceptions and the more updated nature of experts' approaches.

\section{Hungary}

Except for one knowledge-intensive Hungarian SME, all the other seven firms in the sample perceived Industry 4.0 as a set of technologies, usually identifying it with two or three important technological fields, such as automation, robotisation or big data. (Table 1) This result contradicts that of Obermayer et al. (2021) who found that Hungarian managers interpret Industry 4.0 in a holistic way (not only as a set of technologies).

Table 1: Elements of Industry 4.0 mentioned by the company interviewees in Hungary

\begin{tabular}{|c|l|}
\hline Company & \multicolumn{1}{|c|}{ Elements of Industry 4.0 mentioned } \\
\hline$F 1$ & $\begin{array}{l}\text { robotisation, Internet of Things, Artificial Intelligence, digitalisation } \\
\text { robotics, data collection and analysis, visualisation of data, traceability of the } \\
\text { materials used in production }\end{array}$ \\
F3 & automation, new products demanded due to Industry 4.0 \\
F4 & automation, digital technology, sensors, digitalisation (of management) \\
H1 & $\begin{array}{l}\text { automation, digitalisation, robots } \\
\text { H2 }\end{array}$ \\
Big Data & $\begin{array}{l}\text { data collection and sampling, Internet of Things, sensors, Big Data, } \\
\text { digitalisation, 3D printing, on which a new company strategy can be based }\end{array}$ \\
H4 & robots, automation \\
\hline
\end{tabular}

Source: interviews conducted in the framework of the project

Furthermore, we have found an interesting difference between foreign-owned and Hungarian-owned companies: the interviewed foreign-owned subsidiaries had a similar, narrow perception, i.e. identifying Industry 4.0 just with a set of new technologies, with the difference that they usually mentioned not two or three, but three or four dominant technologies in connection with Industry 4.0. Here also robotisation, automation, 3D printing, big data, data visualisation, use of sensors, artificial intelligence, Internet of Things, Artificial Intelligence were mentioned. (Table 1) One subsidiary (F4) identified Industry 4.0 with better, more efficient organisation of production. Interestingly, it deemed these technologies unnecessary overall, as their production organisation is so efficient that they cannot really improve it further. According to the interviewee, when technologies develop further, they may consider the introduction of sensors and big data in order to improve the efficiency of the workers in terms of the movements they make. 
The only exception was the Hungarian SME with highly knowledge-intensive activities and technology-based services. (See Table 1, H3.) This company interpreted Industry 4.0 in a very complex way, embracing all of its elements and the links between them and the company representative thought, Industry 4.0 can help the company to improve its market position, to access new niches in terms of activities/products but also in terms of foreign markets. (See box Company case: The most "active" in Industry 4.0 firm in Hungary.) We assume, there can be other such innovative, usually small-sized firms in Hungary - and in the other Visegrad countries, which really understand the opportunities provided by Industry 4.0.

\section{Box 1: Company case: The most "active” in Industry 4.0 firm in Hungary}

This Hungarian SME was established in March 1990, and it is 100\% Hungarian-owned. The owners are five Hungarian private persons. The firm provides facilities and services for vehicle examination, technical tests, end-of-line tests, and they produce (or rather put together) the equipment for such services; basically, they build unique equipment for their customers.

The company started to export in 2008-2009 only (which was motivated by the shrinkage of the domestic market due to the financial crisis). At present, they export to 11 European countries and India. Exports at present represent $25 \%$ of sales; thus, the company can be evaluated as internationalised.

The firm employs 100 workers, of which there 45 engineers, which is the result of a gradual increase over 30 years. Their production is highly R\&D intensive, and they also produce equipment for $R \& D$ activities. Many activities of the firm are related to Industry 4.0; they gradually learned and adapted these technologies.

Examples of Industry 4.0-related activities:

1. Data sampling is Internet of Things-related: the main aim of collecting and analysing a large amount of data is to find weaknesses in production, usable in wide technical fields; testing - collecting and evaluating a large number of data for partner firms.

2. The company developed oil-distribution systems for oil-producing and vehicle service companies, where they handled a broad set of customer data - here their system distributes oils, screen washer fluids, anti-freeze fluids; e.g. they supplied the Budapest public transport company with that type of services.

This company considers Industry 4.0 as an opportunity through going to niches, which are perceived in two senses: one is new activities, where the leading (multinational) firms do not want to go (they consider these too small problems and too small markets). Second, new markets, where the leading firms do not want to go (afraid of leaking technology and deem the projects not so lucrative) - that is how the firm got to India. Source: Éltetô and Sass (2020) 
This difference between Hungarian-owned and foreign-owned companies seems to be persistent according to the literature (see, e.g. Szalavetz, 2017). These survey results were reinforced by the information gained from the interviews with experts. Academic experts underlined that the common perception of Industry 4.0 among Hungarian companies is usually about just the set of technologies (in individual companies even only one new technology), i.e. Industry 4.0 in a narrow sense. This opinion was shared by the industry experts as well. According to one industry expert (I2), the most common understanding of Industry 4.0 by Hungarian firms is connected to collecting data and analysing them even in fields, which were previously not covered by data collection and analysis (e.g. the production process itself). Hungarian companies want to see more data and want this to help their decision making process, make it more objective, and make the company more transparent. They hope that with big data they can improve efficiency, in terms of using less resources for production, especially in terms of manpower.

One industry expert (I1) explained the gap between foreign-owned and domesticallyowned companies with the following. First of all, according to him, any understanding of Industry 4.0 characterizes around one third of the total number of companies in Hungary, including both foreign-owned and domestically-owned ones. In his understanding, Industry 4.0 is part of a longer-term strategy, as for around one and half- two years, companies first just spend money on it, and they can get the "harvest", i.e. the benefits of applying such technologies, after that period. Thus costs arise immediately, while benefits occur only with a significant time lag. In Hungary, around half of foreign-owned companies and around $13-15 \%$ of Hungarian SMEs have a strategy for at least 2 years. (Similar results can be found in the literature. According to survey results of Nick (2018), only 8.5\% of Hungarian companies have a digital strategy, which is already operational or is to be introduced. Even for foreign-owned subsidiaries, this ratio is $26 \%$. An overview of various survey results also supports the view that especially Hungarian SMEs have serious problems with digitalisation or applying other elements of Industry 4.0, in spite of the fact that they are aware of their importance in increasing competitiveness, or in some casing just helping the survival of companies [Szabó, 2018].) This explains the extremities - basically firms with longer term strategy are those, which have built-in at least some elements of Industry 4.0 into their strategy, which take these elements into account when they plan the future of their firm. This is actually supported by the quote from one company representative (D2), who noted that his company invests in Industry 4.0 (digital technology); however, it is difficult to identify the return on this investment yet. Furthermore, both our industry experts (I1 and I2) emphasized differences among Hungarian companies (both foreignowned and domestically owned) according to their activities and sectors-industries of operation. Certain industries (electronics, automotive, medical instruments) and certain activities (innovative ones) have simply a higher inclination to apply these technologies. On the other hand, academic and industry experts emphasised the complexity of Industry 4.0 in terms of consisting of various technologies and introducing changes in business models (except U1). According to one expert (U2), it can be defined as the use of new digital technologies to enable significant business improvements (such as enhancing customer experience, streamlining operations or creating new business models). According to the 
most nuanced view of one academic expert (U3), the term "Industry 4.0" originally refers to the introduction of a set of new technologies into practice, but over time the original concept has been broadened. However, he thinks we should differentiate the narrow view of "Industry 4.0" and a broader one, which also includes those changes that these technologies induce in the economy, e.g. the development of a new business model, changing social relationships etc. There is a possibility to refer to these broader changes as the " 4 th industrial revolution" and so make it clear whether one is referring to the narrower set of changes or the more general trends. In his view, the two - new technologies and new business models - are related to each other (representing a narrower or a broader perception) and sometimes it is not possible to separate them from each other.

\section{Poland}

In Poland, the company sample was smaller than in Hungary; however, the results were very similar. Polish companies are aware of the importance of Industry 4.0 and the related technologies and identify Industry 4.0, mainly with these new technologies. However, they seem not to properly recognise the practical benefits. As it was already mentioned, the original definition of Klaus Schwab a few years ago sees Industry 4.0 as a set of different technologies. This is a very capacious term for many, still too abstract. As stressed by business representatives (B4) "As life examples show, until entrepreneurs see concrete benefits, it is difficult for them to convince themselves to implement these technologies".

Table 2: Elements of Industry 4.0 mentioned by all types of interviewees in Poland (B-business, E-experts, A-academia)

\begin{tabular}{|c|c|}
\hline Interviewees & Elements of Industry 4.0 mentioned \\
\hline$B 1$ & set of technologies, ecosystem, data sharing, new business models \\
\hline E1 & $\begin{array}{l}\text { modern digital technologies (requiring human capital connectivity }-5 \mathrm{G} \text { ) } \\
\text { leading to the emergence of new firms and optimisation of brick and mortar } \\
\text { companies }\end{array}$ \\
\hline$A 1$ & $\begin{array}{l}\text { not only technology but completely new business models turned "upside down" } \\
\text { - e-commerce, matchmaking platforms; new systems and new professions; AI, } \\
\text { deep machine learning }\end{array}$ \\
\hline$A 2$ & $\begin{array}{l}\text { an unprecedented shift of technologies and business models promising many } \\
\text { benefits but with risks attached; AI, RV, AM }\end{array}$ \\
\hline E2 & $\begin{array}{l}\text { more than technology - integration and a new way of cooperation, the concept } \\
\text { of "procurement } 4.0 \text { ", access to data; radical re-engineering - business } \\
\text { reprofiling and rediscovering; robotisation and digitisation }\end{array}$ \\
\hline A4 & automatisation and robotisation \\
\hline$B 2$ & $\begin{array}{l}\text { 3D printing, set of technologies causing significant business models changes } \\
\text { and requiring interoperability and compatibility }\end{array}$ \\
\hline E3 & set of new technologies changing fundamentally business models \\
\hline
\end{tabular}

Continued on next page 


\begin{tabular}{|c|c|}
\hline Interviewees & Elements of Industry 4.0 mentioned \\
\hline E4 & $\begin{array}{l}\text { needs a whole package of parallel accompanying changes; the emergence of } \\
\text { new actors; all about using sensors, AR, or 3D; technology affects the structure } \\
\text { of the factory; reconstruction of the whole cycle and production process; mass } \\
\text { customisation, predictive maintenance; } 5 \mathrm{G}\end{array}$ \\
\hline B3 & $\begin{array}{l}\text { technological changes which induce modification of business models and } \\
\text { functioning of companies; chatboots, web traffic monitoring, online shopping, } \\
\text { AGV }\end{array}$ \\
\hline E5 & $\begin{array}{l}\text { megatrend influencing the whole life, industry, society } 4.0 \text {; artificial } \\
\text { intelligence or robotics; cloud computing }\end{array}$ \\
\hline B4 & $\begin{array}{l}\text { set of technologies which disrupt and transform markets, game-changers with } \\
\text { scope, scale and speed of modifications being colossal; a physical world that } \\
\text { merges with the digital world; breakthrough technology that transforms the } \\
\text { market }\end{array}$ \\
\hline E7 & $\begin{array}{l}\text { not only mechanisation, robotisation and automation but far-reaching } \\
\text { digitisation and integration; way and mean for sustainable development; an } \\
\text { instrument that enables sustainable economic growth while preserving } \\
\text { environmental and demographic objectives; predictive maintenance, the mass } \\
\text { customisation, distributed production }\end{array}$ \\
\hline A5 & cobots, robots, automation; machine learning, artificial intelligence \\
\hline
\end{tabular}

Source: interviews conducted in the framework of the project

On the other hand, the larger expert sample resulted in a set of nuanced views about Industry 4.0 and related topics. Experts point out that although the topic of Industry 4.0 is of vital importance, it is usually not correctly defined and used. As one expert put it: "Industry 4.0 has recently gained media and public opinion attention but is still poorly understood. Industry 4.0 is not only about mechanisation, robotisation and automation - and this view dominates - it is about far-reaching digitisation and integration". According to the expert, in the understanding and definition of Industry 4.0, there are waves. The first wave was in 2011-2015, and then the understanding of Industry 4.0 was about technology - technology dominated the concept of Industry 4.0 - cyber-physical systems, increasing productivity, improving efficiency were in focus. The second wave was basically after 2017-2018, when attention was focused on business models, on a holistic view, on the value-added chain; on the effects not only of production itself but also in post-production, after-sales, distribution, marketing and so on. In fact, from 2020 we have the third wave and, as the European Commission's industrial strategy for the European Union assumes, Industry 4.0 is a mean for sustainable development; an instrument that enables sustainable economic growth while preserving environmental and demographic objectives. In other words, in successive waves, albeit in the short term, we see the evolution of the understanding of Industry 4.0 from pure technology through business models to the instrument of sustainable development. As put by one professor: "I have been observing what has been happening in the field of Industry 4.0 for several years now, and looking at conferences, symposia and academic talks, one can conclude that there are two understandings of the term Industry 4.0. 
The first one is broader and identifies I4.0 with processes emerging in the wider economy (trade, sale, production) - all improvements, which de facto means that we are talking about the economy 4.0. And the second understanding of I4.0 in its strict sense draws attention to the technology, the way it is integrated with data from the market, with management data, which allows us to achieve completely different effects in the form of new products, etc." As one academic expert put it: "Industry 4.0 is not only the technology but above all utterly new business models". Industry 4.0 turns these models "upside-down". Another expert emphasised that if we understand Industry 4.0 narrowly in the sense of technology, this will most probably modify the central stages in the value chain, i.e. production itself. If we adopt the "business model" approach, then also the first and last stages of value-added creation will be modified. Thus, these experts reinforced the importance of our approach in this research project.

Furthermore, experts emphasised that still there is a need for early diagnosis of what Industry 4.0 is in order to have a clear discussion in the academic world. There is a lack of systematic terminology. New applications appear, new systems and new professions emerge, and the old ones die. It happens quickly and brutally, these turns and twists, and changes are incomparably more significant than in the past. The word Industry 4.0 does not reflect the specifics of the issue entirely, as companies build new value based on e-commerce, matchmaking platforms, using completely other business models. Hence, Industry 4.0 is both the technology plus the new business models. It assumes innovation and therefore, new ways of value creation and capture. It is changing all aspects of our life, aspects of functioning our economies and societies. It promises much, but also brings challenges and threats, as it used to be before with previous revolutions. Particular structural shifting, repositioning would inevitably happen. Benefits will materialise on the micro company level and the national level. New avenues of value creation, new products and services, new business models seem the most critical benefits. Hence, undoubtedly, as one expert said, Industry 4.0 is more than technology; it means integration and a new way of cooperation, even closer than the "just in time" idea assumes.

Experts also highlight the sequential aspect of Industry 4.0. According to one expert, "First of all, Industry 4.0 is a new technology, and it is all about using sensors, AR, or 3D. This technology affects the structure of the factory, and it can be compared to the changes introduced by the electrification. Thus, Industry 4.0 is in the first-place new technology, but its application causes reconstruction of the whole cycle and production process". This cross-linking, the sensors' connection of devices makes the setting of the whole process adjust; and the business model is modified. These initial technological changes, resulting in new models, require significant changes in human resources policy, education and training. Furthermore, the experts emphasised the all-embracing consequences of Industry 4.0. According to them, Industry 4.0 is a physical world that merges with the digital world; as a result, entirely new processes are formed. Digital components become inextricably linked to products and services. Industry 4.0 is a breakthrough technology that transforms the market - new players emerge; others fall out. Summing up, experts argue that "Industry 4.0 is more than technology, it's a start for society 4.0 or even life 4.0 is a megatrend that transforms whole societies". 


\section{Czechia and Slovakia}

The results of the analysis of company and expert interviews are similar to the above two Visegrad countries in Slovakia and a little bit different in Czechia, indicating possibly the fact that Czechia may be ahead of the other three countries in terms of the digitalisation of the economy and the application of the new technologies as well as of the presence of an enabling environment (see, e.g. Castelo-Branco et al., 2019; PIE Report, 2019 or the components of the DESI-index or IMD World Digital Competitiveness Ranking, though other analyses resulted in different rank orders, e.g. Beblavý et al., 2019).

In Slovakia, the majority of the respondents understand Industry 4.0 as a set of technologies. Only the youngest respondents from SMEs - similarly to the Hungarian case, understood it either as new business models or in combinations with it. On the other hand, experts perceived it also as a business opportunity resulting in new business models (Ferenčíková and Zacharová, 2020). However, interestingly enough, in Czechia, the interviewed representatives of the business sector view Industry 4.0 as new business models - platforms, specifically: implementation of new technologies for the business and a transformation or as a new attitude, where automatisation is just one part of it. On the other hand, the experts identified Industry 4.0 rather with a new set of technologies (Bič, Vlčková, 2020). Thus, based on the limited set of interviews conducted in our research, the approach of Czech firms may be more complex compared to the companies in the other three countries, while experts have a simpler approach comparatively.

\section{Discussion}

Having interviewed company representatives as well as academic and industry experts helped us to identify the major differences in the perception of Industry 4.0 in the various groups of companies and the explanations thereof.

We could identify essential differences in the understanding of Industry 4.0 between the various groups of companies. Overall, we found that the overwhelming majority of the firms in our samples identified Industry 4.0 with a set of new technologies, which, according to academic experts is rather characteristic for the first "wave" of Industry 4.0 perception and thus points to relative lateness of Visegrad firms in that respect. Furthermore, foreignowned subsidiaries, usually coming from a more developed home business and technology environment, differ from domestically-owned firms in being aware of and familiar with more new technologies. However, there are some outliers in all the four Visegrad countries: certain innovative domestic firms are much closer in their perception of Industry 4.0 to the second "wave", i.e. identifying it with a new business model, bringing new opportunities for the company. In that respect, we may only assume but not state with certainty, given the low number of interviewed firms, that Czechia may be a little bit ahead of the other three countries in that respect, whereby we can find relatively and proportionally more such firms.

According to industry experts, many Visegrad firms see the opportunity in Industry 4.0 connected to collecting data and analysing them even in fields, which were previously not covered by data collection and analysis (e.g. in the production process itself). In their understanding, this may help them to increase efficiency and productivity. They hope 
that with big data, they can improve efficiency, in terms of using fewer resources for production, especially in terms of human resources, which recently has become a scarcity in these countries. However, the COVID-crisis has turned the economic situation upsidedown. This is well illustrated by one interviewed Hungarian company. The interviewee noted that increasing wages in Hungary induce automation, digitalisation, and changes in administration and production. Through the use of Industry 4.0-related technologies (mainly digitalisation in administration and robots in production), they could significantly reduce employment in administration and the firm reduced the number of employees from 221 to 130 in one product's production through better organisation and digitalisation, i.e. through the use of Industry 4.0-related technologies. Another area where companies see the importance of Industry 4.0 related technologies is quality. Technology actually plays a role when quality questions arise.

Industry experts called our attention to the fact that there exist even more considerable differences among the companies compared to what we can see based on our samples. First of all, any understanding of Industry 4.0 characterises rather the minority of the total number of companies, given the fact that Industry 4.0 is part of a longer-term strategy, as for around one and a half- two years, companies just invest in it. They can get the "harvest", the results after that period. As the Polish business representative put it: it is hard to see the practical benefits of Industry 4.0 for companies. Similarly, a Hungarian company representative noted that his company invests in Industry 4.0 (digital technology); however, it is difficult to identify the return on this investment yet. Thus, costs are arising immediately, while benefits occur only with a significant time lag. Therefore, if a company does not have a longer-term strategy (for at least two years) - it may be unable to apply Industry 4.0 related technologies, even if it is aware of their importance. This may be a problem, especially for Visegrad SMEs, as they have serious problems with digitalisation or applying other elements of Industry 4.0. This explains the extremities - basically, firms with long term strategy are those, which have built-in at least some elements of Industry 4.0 into their strategy and take these elements into account when they plan the future of their firm. In Poland the concern among firms arise due to the selective and "island" nature of Industry 4.0 implementation. As put by one expert (E7) "We have some success stories, but these are isolated cases. There is no effect of scale, no mass, and there is no readiness for certain changes in society. Still, many companies and many employees remain in the comfort sphere and do not feel the need to go beyond it".

Furthermore, we can state that sector, activity or industry matter and explain some of the differences. Our industry experts emphasised differences among Hungarian companies (both foreign-owned and domestically-owned) according to their activities and sectorsindustries of operation. Our small sample reinforced that: the SME, operational in the knowledge-intensive sector stood out from the Hungarian sample in its awareness about and use of Industry 4.0 related technologies. The literature also reinforced these differences (see, e.g. Nick, 2018). The case is similar for Poland, as it was supported by experts. Furthermore, Polish experts also emphasised the importance of various new activities arising in connection with Industry 4.0 and thus being affected differently by it (e.g. procurement 4.0). New actors would emerge, new types of blurred sectors would come 
to life and new definitions would be required as the core of investment or production would inevitably change.

An interesting area is the differences among academic experts in terms of their perceptions of Industry 4.0, which stretches between identifying Industry 4.0 with a set of new technologies (one expert in Hungary and Czech experts) to very nuanced and complex views about Industry 4.0 (all other experts). Here the critical idea is that even in academic approaches, there is no common view concerning the definition of Industry 4.0 and that this definition evolves very rapidly over time. Visegrad experts, government representatives and researchers would benefit significantly from a common approach and understanding of this phenomenon. However, it was obvious that the overwhelming majority of Visegrad experts, both academic, industry and government experts, are already aware of the complex nature of Industry 4.0. They usually perceive Industry 4.0 in a complex way, as a development, which may fundamentally change not only production processes but also firm strategies, industries, economies and even societies. In that respect, the experts' views reflected the latest developments in the literature and business life and were completely in line with those in the other, more developed parts of the world economy.

\section{Conclusion}

Industry 4.0 has gained considerable attention in the academic and practical literature recently, including in the Visegrad countries. However, there are different perceptions and views about this phenomenon. Our article addressed the issue of perceptions of Industry 4.0 among Visegrad firms. Based on company interviews, we found, that indeed, the overwhelming majority of firms identifies Industry 4.0 only with a set of new technologies. The length of the set of technologies differs among companies, according to their size, industry and ownership. However, we could find a few innovative small-sized, locally owned firms, which could identify the opportunities offered by Industry 4.0 and adapted their business strategies accordingly. Furthermore, based on expert interviews, we showed the lack of common and shared understanding of Industry 4.0, which could be a basis for nationwide strategies and policy approaches as well as academic interchanges. We also found that academic, industry and government experts perceive Industry 4.0 in a complex way, and they are aware of the latest developments in the academic and business communities around the world. Therefore, the necessary knowledge is there and available in the Visegrad countries to benefit more from Industry 4.0, we should just find the ways how experts could share this knowledge with the firms.

While there are some limitations concerning our research, mainly due to the relatively small samples and possible selection bias concerning the firms, we tried to handle this problem by including interviews with academic, industry experts and representatives of government agencies, who have an overview of developments in the area. Furthermore, the high level of the similarity of responses from companies induces us to think that our results may be generalizable. However, future research can be directed towards having a larger sample of more diverse companies. We deem this research direction vital as it can give a good basis for the elaboration of strategies both at the firm, at the industry and the national economy level in the related areas. 


\section{Acknowledgements}

The project, in the framework of which this article was prepared, has been funded by the Visegrad Fund - Project ID\#21920068. We are also very grateful to all participants of the project and to all our interviewees, who agreed to take part in our survey.

\section{References}

Acemoglu, D., Restrepo, P. (2020). Robots and jobs: Evidence from US labor markets. NBER working paper 23285, National Bureau of Economic Research. Cambridge: Mass. Aghion, P., Jones, B.F. and Jones, Ch. I. (2017). Artificial Intelligence and Economic Growth. National Bureau of Economic Research Working Paper Series No. 23928, October 2017. Available at http://www.nber.org/papers/w23928.pdf.

Angell, J. R. (1906). "Perception”, Chapter 6 In Psychology: An Introductory Study of the Structure and Function of Human Conscious, Third edition, revised. New York: Henry Holt and Company, p. 122-140.

Asadollahi-Yazdi, E., Couzon, P., Nguyen, N. Q., Ouazene, Y. and Yalaoui, F. (2020). Industry 4.0: Revolution or Evolution? American Journal of Operations Research, 2020, 10, 241-268. Available at https://www.scirp.org/pdf/ajor_2020101411112760.pdf.

Bauer, W., Hämmerle, M., Schlund, S., Vocke, C., (2015). Transforming to a hyperconnected society and economy - towards an "Industry 4.0.". Procedia Manufacturing, 3, 417-424. Available at https://doi.org/10.1016/j.promfg.2015.07.200.

Beblavý, M., Baiocco S., Kilhoffer Z., Akgüç, M., Jacquot, M. (2019). Index of Readiness for Digital Lifelong Learning Changing How Europeans Upgrade Their Skills, Final Report - November 2019, CEPS - Centre for European Policy Studies in partnership with Grow with Google.

Bharadwaj, A., Venkatraman, N. (2013). Digital Business Strategy: Toward a Next Generation of Insights. MIS Quarterly, 37(2), 471-482.

Bič, J. and Vlčková, J. (2020). Industry 4.0 and FDI., Czechia. Available at https://industry40fdi.files.wordpress.com/2020/10/czechia-report.pdf.

Buckley, P. J., Strange, R. (2015). The governance of the global factory: Location and control of world economic activity. Academy of Management Perspectives, 29(2), 237-249. Castelo-Branco, I., Cruz-Jesus, F., Oliveira, T. (2019). Assessing Industry 4.0 readiness in manufacturing: Evidence for the European Union. Computers in Industry, 107, 22-32. Ciffolilli, A., and Muscio, A. (2018). Industry 4.0: national and regional comparative advantages in key enabling technologies. European Planning Studies, 26(12), 2323-2343. Corradini, C., Santini, E. and Vecciolini, C. (2021). The geography of Industry 4.0 technologies across European regions, Regional Studies, DOI: 10.1080/00343404.2021.1884216. Cséfalvay, Z. (2019). Robotisation in Central and Eastern Europe: catching up or dependence? European Planning Studies, DOI: 10.1080/09654313.2019.1694647.

Dalenogare, L. S., Benitez, G. B., Ayala, N. F., Frank, A. G. (2018). The expected contribution of Industry 4.0 technologies for industrial performance. International Journal of Production Economics, 204(10), 383-394. 
Dremel, C., Wulf, J., Herterich, M. M., Waizmann, J.-C., Brenner, W. (2017). How AUDI AG established big data analytics in its digital transformation. MIS Quarterly Executive, 16(2), 81-100.

Éltető, A., Sass, M. (2020). Industry 4.0 and FDI. Experiences of Hungary. Available at https://industry40fdi.files.wordpress.com/2020/10/hungary-report.pdf.

Ferenčíková, S., Zacharová, A. (2020). Slovakia. Country report. Available at https://industry40fdi.files.wordpress.com/2020/10/slovakia-report.pdf.

Fifeková, E., Nežinský, E., Nemcová, E. (2018). Global competitiveness of Europe: a robust assessment. DANUBE: Law, Economics and Social Issues Review, 9(4), 245-260.

Hernández, S. R., Martínez, A. D., Domínguez, H. S. R. (2019). The perception of Industry 4.0 in the managers of automobile distribution companies. Journal of Business and Retail Management Research, 14(1), 71-78.

Horváth, D., Szabó, Zs. R. (2019). Driving forces and barriers of Industry 4.0: Do multinational and small and medium-sized companies have equal opportunities? Technological Forecasting \& Social Change, 106, 119-132.

Kagermann, H., Wahlster, W., Helbig, J. (2013). Recommendations for implementing the strategic initiative Industry 4.0. Final report of the industry 4.0 working group, http://www. acatech.de/fileadmin/user_upload/Baumstruktur_nach_Website/Acatech/root/de/Material _fuer_Sonderseiten/Industrie_4.0/Final_report_Industrie_4.0_accessible.pdf.

Lewis, A. (2001). The issue of perception: some educational implications. Educare, 31(1), 272-288.

Miles, M. B., Huberman, A. M. (1994). Qualitative Data Analysis. Sage Publications, London.

Mudambi, R., Li, L., Ma, X., Makino, S., Qian, G., Boschma, R. (2018). Zoom in, zoom out: Geographic scale and multinational activity. Journal of International Business Studies, 49, 929-941. Available at https://doi.org/10.1057/s41267-018-0158-4.

Nick, G. (2018). Az Ipar 4.0 hazai adaptációjának kihívásai a vállalati és területi összefüggések tükrében (Challenges of the adaptation of Industry 4.0 in Hungary in connection with firm-level and regional issues). PhD thesis, University of Györ.

Obermayer, N., Csizmadia, T., Hargitai, D. M., Kígyós, T. A. (2021). Az Ipar 4.0. implementációval kapcsolatos vezetói motivációk és akadályozó tényezők elemzése hazai vállalatvezetốk véleménye alapján. (Analysis of managerial motivations and barriers related to the implementation of Industry 4.0 based on the opinion of Hungarian business leaders. Vezetéstudomány/Budapest Management Review, LII(2), 60-72.

Osarenkhoe, A., Fjellström, D., Abraha, D., Awuah, G. (2020). Networked establishment processes in transition economies. Global Business and Economics Review, 22(1-2), 161-177.

Oztemel, E., Gursev, S. (2020). Literature review of Industry 4.0 and related technologies. Journal of Intelligent Manufacturing, 31, 127-182.

Petropoulos, G. (2017). The growing presence of robots in EU industries. Bruegel, Brussels. Available at http://bruegel.org/2017/12/the-growing-presence-of-robots-in-euindustries/. 
PIE Report (2019). Roads to Industry 4.0. Robotization in the World and Lessons for Poland. Polish Economic Institute (PIE) / Drogi do przemysłu 4.0, Robotyzacja na świecie i lekcje dla Polski - PIE Report 2019.

Rostkowski, D. (2019). Robotyzacja w Polsce: szanse i zagrożenia, Obserwator Finansowy. Retrieved November 19, 2019, from https://www.obserwatorfinansowy.pl/forma/rotator/robotyzacja-w-polsce-szanse-i-zagrozenia/.

Schwab, K. (2016). The Fourth Industrial revolution. World Economic Forum. Geneva. Segal, M. (2018). How automation is changing work. Nature, 563(7733), 132-S135.

Szabó, Zs. (2018). Párhuzamos valóságban élnek a magyar vállalkozók? - Ennek bukás lehet a vége (Hungarian entrepreneurs - living in a parallel reality? - This can result in failures.) Napi, 2018, 16th of April. Available at https:/www.napi.hu/tech/parhuzamos_valosagban_elnek_a_magyar_vallalkozok_ennek_bukas_lehet_a_vege.660679.html.

Szalavetz, A. (2016). Egy előre bejelentett forradalom krónikája Magyarországon. (Chronicle of an announced revolution in Hungary - Industry 4.0 technologies and manufacturing subsidiaries). KÜLGAZDASÁG, 60(9-10), 28-48.

Szalavetz, A., (2017). Industry 4.0 in "factory economies", In: Galgoczi, B., Drahokoupil, J. (Eds.), Condemned to Be Left Behind? Can Central and Eastern Europe Emerge from Its Low-Wage Model? European Trade Union Institute (ETUI), Brüsszel, pp. 133-152.

Szalavetz, A. and Somosi, S. (2019). Ipar 4.0 - technológiák és a magyarországi fejlődésfelzárkózás hajtóerôinek megváltozása - gazdaságpolitikai tanulságok = Impact of industry 4.0 technologies on the engines of development and catch-up in Hungary - Some lessons for economic policy. KÜLGAZDASÁG, 63(3-4), 66-93.

Tay, S. I., Lee, T. C., Hamid, N. A. A., Ahmad, A. N. A. (2018). An Overview of Industry 4.0: Definition, Components, and Government Initiatives. Journal of Advanced Research in Dynamical and Control Systems, 10(SI), 1379-1387.

UNIDO (2020). Industrial Development Report 2020. Industrializing in the digital age, Overview.

Veugelers, R., Rückert, D., Weiss, Ch. (2019). Bridging the divide: new evidence about firms and digitalisation. Policy Contribution, (17), December.

Yermack, D. (2017). Corporate governance and blockchains. Review of Finance, 21(1), 7-31. 